\title{
Multidimensional Comparison of Lightweight Steel and Reinforced Concrete Structures: A Case Study
}

\author{
Tolga ÇELIK, Saeed KAMALI
}

\begin{abstract}
Lightweight steel construction has some undeniable advantages over concrete construction; however, reinforced concrete structures are used ubiquitously in Mediterranean countries and therefore most of the scientific studies have been focused on the reinforced concrete structures. One of the main reasons for not using the lightweight steel construction widely is lack on knowhow about this method. This study is aimed at raising the knowledge about the technical features of cold-formed steel members as well as advantages of lightweight steel structure in comparison with reinforced concrete. To fulfil this aim, a case study was conducted to compare lightweight steel structure with reinforced concrete structure in different points of view in detail. From the case study, it is found out that the building total covered area and mass designed by reinforced concrete structure are $2.6 \%$ larger and 9 times greater than the lightweight steel structure respectively. It was also concluded that the total cost (indirect and direct) and construction duration for the reinforced concrete structural frame are approximately $17.7 \%$ and $70.9 \%$ respectively higher than constructing the lightweight steel structural frame.
\end{abstract}

Keywords: life cycle cost; lightweight steel construction; reinforced concrete construction; sustainability

\section{INTRODUCTION}

Selecting the type of structural frame to be utilised in construction has a dominant act upon the value of the construction as the structural frame supplies both functionality and future flexibility. In addition, it is the structural frame that dictates the speed and overall building cost of the construction process. In addition, selecting the type of structural frame is quite important as it comes together with many other components of the building affecting their specification and buildability.

Choice of material to be used as structural frame is highly dependent on the type of building to be constructed and site-specification constraints [1]. Even though the choice of structural frame is mainly affected by the issues related to the project, the type of main structural frame is generally decided by cost showing less importance to the functionality and performance characteristics. This was confirmed to be true by Idrus and Newman (2003) who have stated that structural frame selection guidelines and rules frequently focus on time and cost requirements [2].

Despite the fact that various options of the building construction methods are available, mainly structural steel or reinforced concrete is being utilized in constructions [3]. Currently, reinforced concrete is one of the most essential structural materials. Additional to the reinforcing steel, the basic ingredients of concrete are cement, aggregates and water which are locally available in almost every country. This is why reinforced concrete materials are used ubiquitously. However, in some countries obtaining aggregates from the nature results with complaints of environmentalist organizations. One of the solutions for this problem is to use steel as structural element. In addition, steel construction, especially lightweight steel construction, has some advantages over concrete construction. These advantages are high strength to weight ratio, high quality material readily available in various certified grades, shape and sizes, easy and fast construction on the site, ease for modification, repair and demolition, flexibility for architectural and aesthetic designs, high durability and environmentally friendly [4, 5]. If the construction details are carefully analysed and applied on the site, steel construction yields better heat and sound isolation, longer economical life and better quality of the product. This is why there is a trend in the world for using more steel in construction sector $[5,6]$.

Currently steel construction, especially lightweight steel construction, is not widely used in Mediterranean countries. This could be the result of lack of knowledge about lightweight steel construction and unfamiliarity with this system [7]. Therefore, the main purpose of this research was fixed to improve the knowledge about lightweight steel construction. This paper is intended to contribute to introduce lightweight steel structure and provide a multidimensional comparison between lightweight steel structure and reinforced concrete structure from quantitative (lightness, construction duration and initial cost) and qualitative (aesthetics, impact of weather conditions on construction activities and easiness of installing plumbing/electricity) points of view. In order to provide a more realistic comparison, a case study (two-story detached villa) has been designed by both lightweight steel construction and reinforced concrete structure with exactly the same indoor dimensions to analyse and compare the abovementioned quantitative and qualitative parameters.

\section{LIGHTWEIGHT STEEL CONSTRUCTION}

Cold-formed steel members are widely used in building construction, bridge construction and transmission towers. These sections are cold-formed from carbon or low alloy steel sheet, strip, plate, or flat bar in cold-rolling machines or by press brake or bending brake operations [8]. Most of the steel sheets used in lightweight steel construction have yield strength of $\sigma_{\mathrm{y}}=320$ or $350 \mathrm{MPa}$ plus they are constantly hot-dip galvanized [8]. The thickness of the sections varies from $0.38 \mathrm{~mm}$ to 6.35 $\mathrm{mm}$ providing adequate static standards for multi-storey residential buildings $[8,9]$.

Cold-formed steel members have some merits in comparison with concrete such as lightness, high strength and stiffness, and fast and easy erection and installation. In terms of structural design, Yu W. W. divided cold-formed 
steel members into individual structural framing members and decks $\&$ panels $[5,9]$.

The main individual framing members function is to carry load thus structural strength and stiffness are the most important considerations in design. The individual structural framing members can be utilized as main framing members in buildings of up to five stories. In higher buildings, the primary elements are generally of heavy hot-rolled sections and the secondary ones such as wall decks, joists, panels or studs might be of cold-formed steel sections. The cold-formed and the heavy hot-rolled steel sections complement each other in this case. In addition to the steel decks ability to carry loads, they also provide a surface on which roofing, flooring or concrete fill can be applied [8]. Moreover, steel decks are used as formwork during construction and as reinforcement after the concrete hardness in composite slab systems. Furthermore, if load-carrying panels and decks are appropriately interconnected to each other as well as supporting members, they not only withstand loads normal to their surface, but can also act as shear diaphragms to resist forces in their own planes [10-12].

Cold-formed steel structure design standards are available in Sweden [13], UK [14], Australia [15], US [16], Canada [17], China [18], Finland [19], France [20], Germany [21], India [22], Japan [23], Netherlands [24], New Zealand [25], South Africa [26] and elsewhere. Since 1975, the European Convention for Constructional Steelwork [27] has prepared a number of documents for the design and testing of cold-formed sheet steel used in buildings. Eventually, Eurocode 3 contributed design information for cold-formed steel structures in 1989 [8].

Due to the high strength capacity of steel materials, the strength to weight ratio of steel construction creates structures with low overall environmental impacts, requiring fewer and smaller foundation than other construction methods. Steel construction creates wellinsulated and air-tight dwellings that contribute to obtain better energy efficiency. Steel construction is highly sustainable. Its sustainability is inherently characterised by its: low waste, flexibility, offsite manufacture, speed, resource efficiency, adaptability, demountability, long lasting appeal, safety, reusability and recyclability. Light gauge cold rolled steel (lightweight steel) frame panels offer benefits in construction such as high-load bearing capacity, lightness and an extensive variety of possible utilizations. Fairly large amount of residential buildings is being constructed at low price by lightweight steel sections in some countries [9].

Construction using cold-formed structural steel members does not involve heat input and its associated expenditures. Elements used in cold-formed construction are thinner, their production rate is faster and finish is smoother. When these parameters are combined, it can be said that cold-formed steel construction has lower construction cost compared with equivalent but heavier hot rolled steel products like I-beams or channels.

\subsection{Fire Protection of Cold-Formed Structural Steel Members}

In circumstances where the temperature raises over $500^{\circ} \mathrm{C}$, the load bearing capacity of steel in terms of strength and ductility falls linearly [28]. Steel elements are fire-resistant. Even though they are mainly used in thin walls or lightweight frames they have no fire-resistant characteristics themselves unless they are guarded against the consequences of high temperatures throughout fire. Panel sheathing is the only way of stopping serious plastic deformations and static failure of the construction elements as it acts like a thermal sheathing for the steel elements.

In order to prevent the spreading of fire into adjacent rooms or on to the other floors, components such as the floors and walls have to be capable of gathering the conditions given below with respect to their fire resistance [6]:

- prevent the spread of fire,

- tightness towards the combustible gas,

- restraint of the temperature of the surface against the fire surface.

Light gauge steel structure elements' fire performance is obtained by the following factors:

- fire stress,

- construction process,

- static system

- acceptable dynamic load for the member,

- construction materials.

\subsection{Corrosion Control of Cold-Formed Steel Structures}

Cold rolled profiles are fabricated by hot-dip galvanized iron strips. Galvanization is a superior method of controlling corrosion on constituents for a period equivalent to the structure's service life if the construction details and different coverings have been accurately designed and implemented [28].

Under normal climatic conditions, exterior building has disintegration of $0.1 \mathrm{~g} / \mathrm{m}^{2}$ of zinc yearly because of corrosion. This is why the defending layer has a life span which is a lot longer than the life span of a building. In addition, zinc has a feature of self-healing its destroyed elements by cathodic reaction [28].

\subsection{Advantages of Lightweight Steel Framing 2.3.1 Weight}

For a specific building, the dead load of reinforced concrete skeleton was obtained as 1450 tons, where the structure of the same building could be constructed by 718 tons of steel [29]. Moreover, generally, the dead load of a building constructed by light weight steel is only about $10 \%$ of the dead load of equal size reinforced concrete building [28]. The benefits of reducing the dead load of buildings are as follows [7]:

- the effect of earthquake on the building is proportionally less,

- the structural elements and foundation will carry fewer loads, so it will be cheaper.

\subsubsection{Thermal Performance}

Steel's energy efficiency is one of the main concerns. CSSBI stated that energy efficiency depends on the entire home acting as a system, from the basement to the attic including the space conditioning equipment. In addition, it 
is said that air filtration is responsible for most of the energy lost in the house where main heat loss is attributed to air leakage through the building envelope [30].

Even though steel's conduction rate is more compared to the other structural frame materials, steel is only one of several components within a building envelope, which is designable to offer an effective thermal barrier. In order to validate this by sponsorship of American Iron and Steel Institute, National Association of Home Builders Research Centre developed R-values for typical cold-formed steel framed walls. It was found out from this research that the $\mathrm{R}$-value for steel framed walls is not very much affected by the thickness of the steel studs as stud's web thickness is little limiting the heat conduction.

Moreover, it is known that when cold-formed steel is utilized as main frame of a building where the steel thickness is thinner compared to hot rolled steel, shape of framing tolerates for better quality heat insulation to be inserted into spaces instead of normally occupied low Rvalue wood. Furthermore, unlike kiln-dried wood framing, which has moisture content of nearly about $19 \%$, steel remains straight and true once tensioned despite the consequence of contacting with moisture. In this way, it can be said that steel framed structures do not wrap or shrink [30].

\subsubsection{Life Cycle Cost}

In life cycle cost calculations, in addition to the initial cost and considering the time value of money, operation costs, repair and maintenance costs, salvage costs also are to be included. In a life cycle cost analysis, the energy consumption of steel structures was calculated as only $75.1 \%$ of the energy consumption of concrete structure [31]. Since steel framing does not dry out and shrink over time, steel construction requires less maintenance and repair cost [32]. At the end of its economic life time all the steel elements can be unbolted and used again in another construction or in the worst case can entirely be recycled. Thus, it has a plus salvage value. However, in a concrete construction, at the end of its economic life time, money is to be spent to demolish and remove it considering that the change of recycling is less.

\subsubsection{Quality}

All steel elements are produced, cut or bent in factory medium mostly controlled by means of a computer. Thus, the quality of these elements is controlled better than the site produced concrete elements. The levels and lines of factory produced steel elements are perfect. Some assembling of the elements is also performed in the factory medium. Therefore, the steel structure provides better quality than concrete structures [7].

\subsubsection{Flexibility and Adaptability}

Due to the characteristics of steel elements, spacious rooms can be built. Long spanning structural steelwork system provides areas freed from columns where this situation enhances the flexibility of floor layout, architectural design and improves the functionality of the space. In addition to these steel partition walls which are light and can easily be repositioned the structure can be adaptable according to the future needs. However, besides the fact that concrete elements are not future adaptable they are larger in size and that results with loss of space. Furthermore, utilization of concrete elements does not allow having larger spans as steel elements do [29].

\subsubsection{Construction Duration and Predictability}

The duration of reinforced concrete skeleton construction is three times longer than that of the steel structure construction. With the help of off-site prefabrication of steel framed structures, the speed, quality and the safety of construction are enhanced. In addition, utilization of steel framed buildings rather than reinforced concrete structures enhances the predictability of the cost as well as the construction schedule. The amount of time saved by using steel framed structures rather than reinforced concrete framed structures results with $2-3 \%$ of saving in terms of the overall building cost [29].

\subsubsection{Sustainability}

Products made up of steel including cold-formed steel framing are $100 \%$ recyclable. CSSBI reported that one of the significant attributes of steel is its ability to be recycled without any loss or degradation of its inherent material properties, allowing it to exist for an infinite number of product life cycles.

In North America steel industry where over 80 million tons of steel were recycled in 2006 there is a single largest recycler. Some countries report that their steel recycling is as high as $85 \%$ while in Canada this number was about $53 \%$ making an average of 8 million metric tons being recycled [30].

Recycling steel and using recycled steel in constructions takes pressure off from the renewable sources. For instance, $186 \mathrm{~m}^{2}$ of a house, framed with coldformed steel only requires the equivalent of roughly six scrapped automobiles where the same size house framed with wood needs lumber from 40-50 trees, which is nearly an acre worth of forest [30].

Steel recycling is significant for the environment as it directly affects the industry's energy performance. Steel making processes such as Basic Oxygen Furnace and Electric Arc Furnace together recycle very large amount of scrap steel in making new steel annually. In addition to this, conserving important amount of energy and other natural resources while reducing emissions can be achieved through these steel production processes. Utilization of old steel products as well as other forms of ferrous scrap during the production of steel reduces a variety of steel manufacturing costs and lowers the amount of energy consumed in production stage by $75 \%$ [30].

For each ton of steel recycled in the sector about $1130 \mathrm{~kg}$ of iron ore, $635 \mathrm{~kg}$ of coal and $55 \mathrm{~kg}$ of limestone is saved. In the USA with the help of recycled steel the industry saves sufficient energy to power about 18 million homes annually [30].

Construction sites, especially in urban areas have been causing a lot of adverse impacts on the environment in terms of wastes due to execution of construction projects such as: demolishing, building, and infrastructure works 
[33-35]. As a matter of fact, it is worth to mention at this stage that decision makers, besides adopting and applying waste management strategies in construction projects, are also considering alternative construction methods. Concrete structures have the maximum wastage and the steel structures have the minimum wastage among other construction materials [7].

During the construction on the site, since the steel framing members are manufactured with pre-punched holes for running piping and electrical wiring, there will be minimizing preparation work for other trades. On the other hand, steel framing accommodates all types of commonly used finishing materials [7]. In addition, in terms of the materials delivering, compared to the ingredients of concrete such as sand, aggregates, concrete (if on-site production) etc., delivering steel materials to the site is relatively easy. Light weight steel structures constituents especially require no heavy lifting mechanism for loading and unloading purposes.

As mentioned previously steel is $100 \%$ recyclable without losing its quality. Nowadays in UK, buildings which have already been built steel framed and come to the end of their useful lives provide $86 \%$ of the steel section to be recycled in order to create more steel products and provide $13 \%$ of the steel section to be functioning in the existing form. Recycling rates for the reinforcement bars used in concrete framed structures are negligible compared to the recycling rates of steel used in steel framed structures [7].

Cold-formed steel structural frame members are types of construction materials which do not seem to be found in landfill or buried at a construction site. Distinguishing it from too many other materials is the fact that steel is routinely collected in aggregate quantities from construction and demolition sites since any scrap generated on the job-site has a resale value.

Not like reinforced concrete framing or timber framing, the consistency of steel framing members helps to mitigate waste as there is no need to discard material due to splitting, wrapping or twisting. Also, waste is minimized during the construction phase as cold-formed steel framing is prefabricated resulting with less cutting being required in construction site. CSSBI stated that constructing a $186 \mathrm{~m}^{2}$ wood-framed house forms roughly $1.4 \mathrm{~m}^{2}$ of landfill waste while a steel framed house generates nearly $80-90 \%$ less waste [30].

Nowadays due to its reduced overall environmental impact and faster construction time, in the USA multifamily residential buildings have become more prevalent. Due to its prefabrication, wall and floor panels as well as roof trusses arrive at the construction site pre-assembled leading to minimized on-site cutting, meaning no debris, dumpsters and large stacks of lumber strewn around construction site [30].

\section{CASE STUDY: COMPARISON OF LIGHTWEIGHT STEEL AND REINFORCED CONCRETE STRUCTURE}

The conducted comparison of two alternative construction methods is discussed widely within seven different steps that were comprised on the basis of technical/architectural concept, total mass of the structural frame and building, weather conditions, installation of plumbing/electrical works, doors and windows, physical properties, initial cost, and construction duration. The comparison of the construction method alternatives has been conducted with respect to a two-storey detached villa. The architectural drawing for the villa is depicted in Fig. 1.

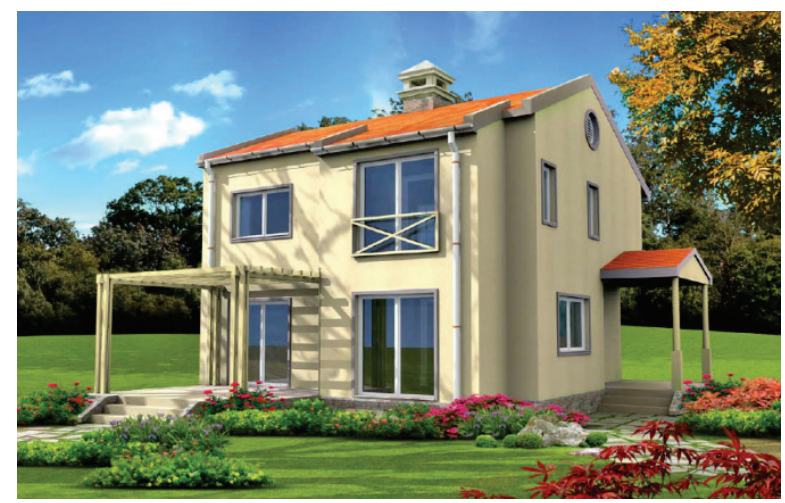

Figure 1 Two storey detached villa designed for this specific case study

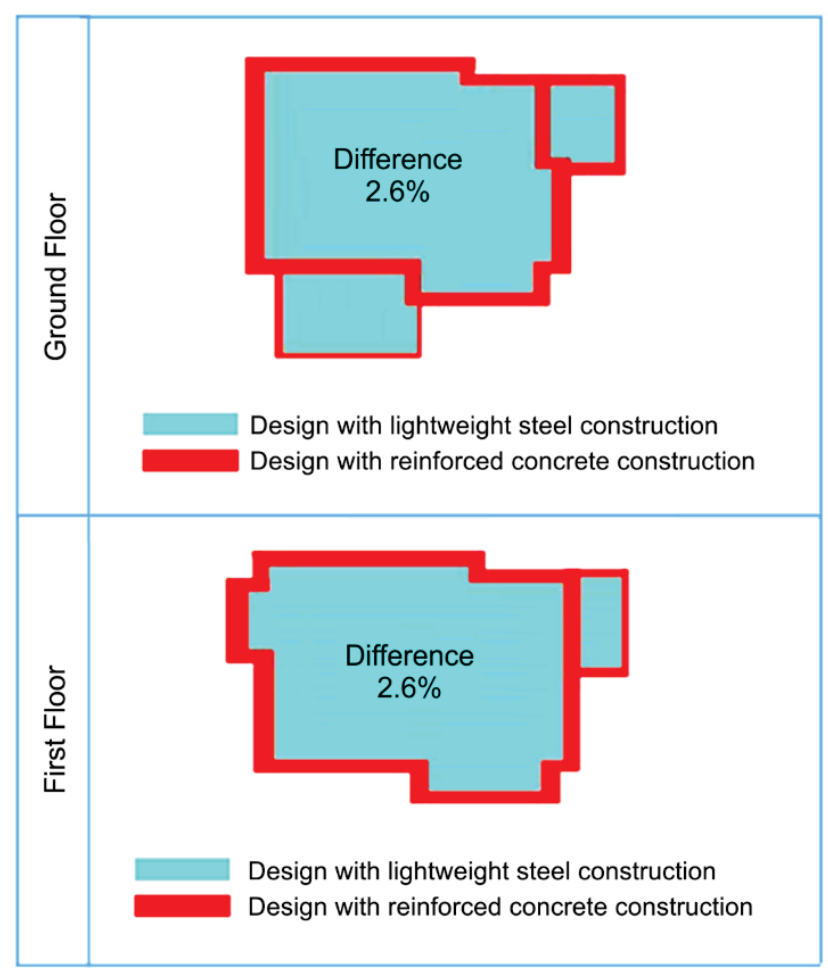

Figure 2 Overlapping of designs with alternative construction methods

\subsection{Architectural Concept}

In this step, detached two-storey villa illustrated in Fig. 1 is designed for two different construction methods in a way that for both designs indoor dimensions of the villa were kept the same. Within this context, it is obtained that the villa designed by lightweight steel construction occupied $2.6 \%$ lesser area compared to the villa designed by reinforced concrete construction. This outcome is supported by Figs. 2 and 3. In line with this, it can be said that if there is a specific land and detached two storey villas are to be constructed on it, by adopting lightweight steel construction method, 1026 villas can be designed and fitted on this land where with reinforced concrete construction method only 1000 can be designed and fitted to the same piece of land. 
Table 1 Comparison of total covered area of the detached two-storey villa (The usable internal areas of both alternatives are the same.)

\begin{tabular}{|c|c|c|}
\hline & $\begin{array}{l}\text { Reinforced Concrete } \\
\text { Architectural Design }\end{array}$ & $\begin{array}{l}\text { Lightweight Steel } \\
\text { Architectural Design }\end{array}$ \\
\hline \multirow{3}{*}{$\begin{array}{l}\text { Ground } \\
\text { Floor }\end{array}$} & Closed Space: $71.6 \mathrm{~m}^{2}$ & Closed Space: $69.8 \mathrm{~m}^{2}$ \\
\hline & $\begin{array}{l}\text { Closed Roof Space: } \\
7.91 \mathrm{~m}^{2}\end{array}$ & $\begin{array}{l}\text { Closed Roof Space: } \\
7.57 \mathrm{~m}^{2}\end{array}$ \\
\hline & $\begin{array}{l}\text { Total Closed Space: } \\
79.51 \mathrm{~m}^{2}\end{array}$ & $\begin{array}{l}\text { Total Closed Space: } \\
77.37 \mathrm{~m}^{2}\end{array}$ \\
\hline \multirow[t]{4}{*}{$\begin{array}{l}\text { First } \\
\text { Floor } \\
\end{array}$} & $\begin{array}{l}\text { Total Closed Space: } \\
75.68 \mathrm{~m}^{2}\end{array}$ & $\begin{array}{l}\text { Total Closed Space: } \\
73.8 \mathrm{~m}^{2} \\
\end{array}$ \\
\hline & $\begin{array}{l}\text { Total area of the villa: } \\
155.1 \mathrm{~m}^{2}\end{array}$ & $\begin{array}{l}\text { Total area of the villa: } \\
151.19 \mathrm{~m}^{2}\end{array}$ \\
\hline & $\begin{array}{r}\text { Total area d } \\
\text { Total area propor }\end{array}$ & $\begin{array}{l}\text { ce: } 4.02 \mathrm{~m}^{2} \\
\text { difference: } 2.6 \%\end{array}$ \\
\hline & Claddin & parison \\
\hline \multirow[t]{3}{*}{ Area } & $\begin{array}{l}\text { Total external surface: } \\
251.62 \mathrm{~m}^{2}\end{array}$ & $\begin{array}{l}\text { Total external surface: } \\
245.75 \mathrm{~m}^{2} \\
\end{array}$ \\
\hline & $\begin{array}{l}\text { Total external surfac } \\
\text { Total external surface } \mathrm{p}\end{array}$ & $\begin{array}{l}\text { difference: } 5.87 \mathrm{~m}^{2} \\
\text { onal difference: } 2.33 \%\end{array}$ \\
\hline & Roof surface & comparison \\
\hline \multirow[t]{2}{*}{ Area } & $\begin{array}{c}\text { Total roof surface: } \\
85.69 \mathrm{~m}^{2} \\
\end{array}$ & $\begin{array}{c}\text { Total roof surface: } \\
85.25 \mathrm{~m}^{2}\end{array}$ \\
\hline & \multicolumn{2}{|c|}{$\begin{array}{l}\text { Total roof surface area difference: } 0.44 \mathrm{~m}^{2} \\
\text { Total roof surface proportional difference: } 0.51 \%\end{array}$} \\
\hline
\end{tabular}

Moreover, additional variations in terms of total external surface area and total roof surface area occurred due to differences in wall thickness and main structural frame elements' dimension differences when two alternative construction methods are compared. Tab. 1 gives these variations.

\subsection{Total Mass of Structures Frame and Building}

After a comprehensive literature review it was found out that structures constructed by lightweight steel are extremely light compared to reinforced concrete construction method [7, 36]. In line with this, relevant static calculations were performed for the aforementioned two-storey detached villa as a part of this case study. Results of the static calculations indicated that know how obtained from the literature has overlapped with the reallife practice in this case study as the total mass of the villa designed with reinforced concrete structural frame was 97.1 tonnes where it was only 5.5 tonnes for the villa designed with lightweight steel structural frame. In addition, total mass of the building for the villa designed by reinforced concrete construction was 151.7 tonnes where this number was only 16.9 tonnes for the villa designed by lightweight steel construction.
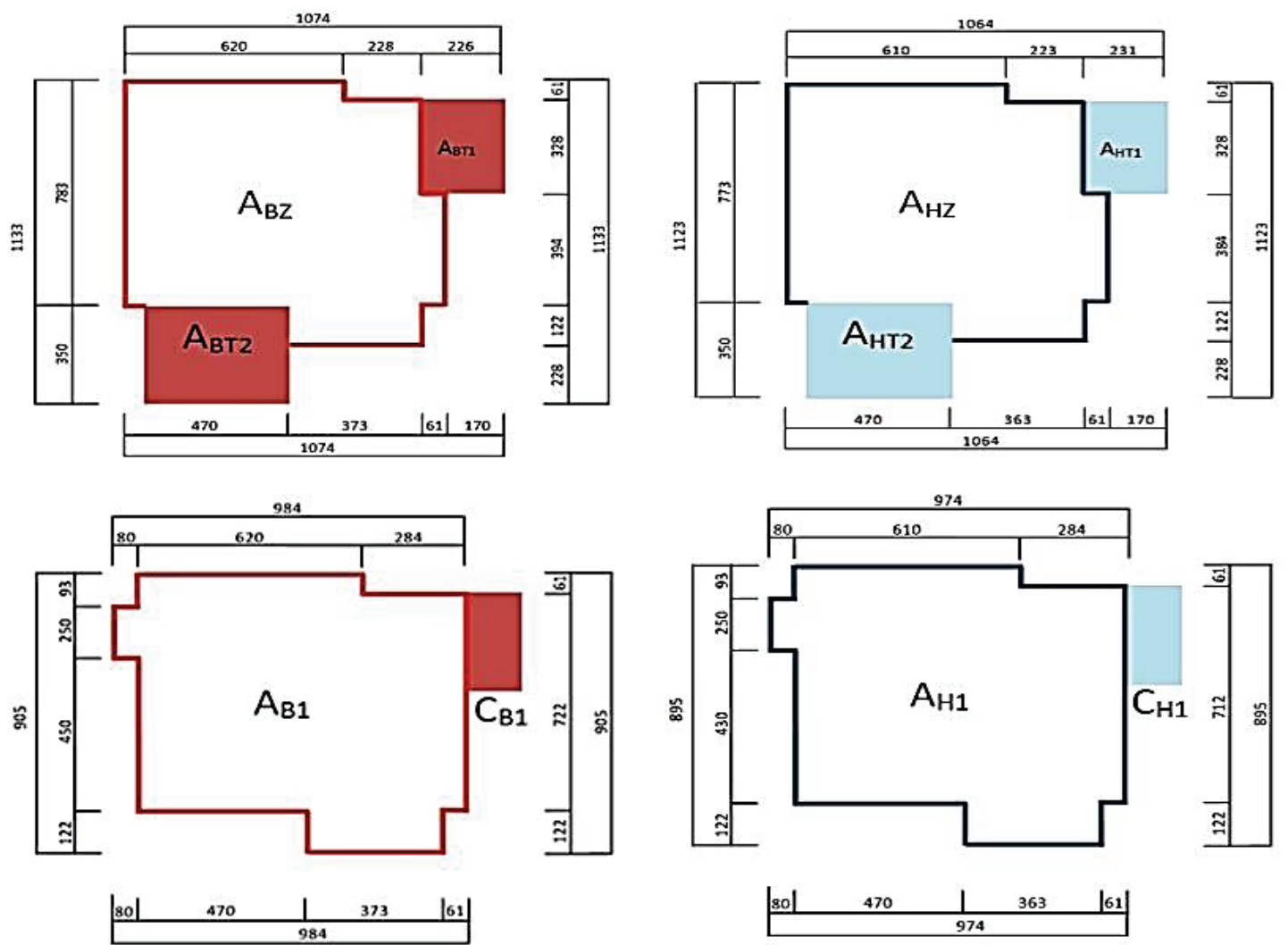

Figure 3 Floor plans comparing occupied area of detached two-storey villa for two different construction methods $\left(A_{\mathrm{BZ}}\right.$ - ground floor area of reinforced concrete construction, $A_{\mathrm{Hz}}$ - ground floor area of lightweight steel construction, $A_{\mathrm{B} 1}$ - first floor area of reinforced concrete, $A_{\mathrm{H} 1}$ - first floor area of lightweight steel construction)

In accordance with the static calculations, total mass of the structural frame for the villa designed by reinforced concrete construction was obtained to be 18 times heavier compared to the villa designed by lightweight steel construction. Additionally, total mass of the building for the villa designed by reinforced concrete construction was 9 times heavier compared to the villa designed by lightweight steel construction.
It was obtained from the literature that lightweight steel structures, due to reduced total dead load of the building are more resistant to earthquakes compared to reinforced concrete construction $[7,36]$.

The two consequences due to differences in total mass of the aforementioned villas are as follows:

- Effect of magnitude of earthquake over a structure is directly proportional to the total mass of the building. In case of an earthquake villa designed by reinforced 
concrete construction method will face the impact of the seismic activity 6 times greater than the villa designed by lightweight steel construction due to abovementioned lightness parameter. This is due to the fact that lateral force of 25.3 tonnes from a probable earthquake is expected to apply on the villa designed with reinforced concrete construction where the lateral force of only 4.2 tonnes from a probable earthquake is expected to apply on the villa designed with lightweight steel construction,

- In this case study, soil bearing pressure for the villa designed by lightweight steel construction is calculated to be $24.5 \mathrm{kPa}$ where this number is $61.29 \mathrm{kPa}$ for the villa designed by reinforced concrete construction. In line with this, it can be said that lightweight steel construction required shallower excavation compared to reinforced concrete construction which also leads to lesser construction duration. Additionally, the difference between construction methods in terms of the quantity of excavation works leads to lessening the intensity of nuisance that third parties were exposed to hence lesser social cost occurred and this has helped to decrease total construction cost [37].

The results in which lightweight steel and reinforced concrete construction methods are compared in terms of the total mass of the structural frame and total mass of the building were given in Tabs. 2, 3, 4 and 5 .

Table 2 Reinforced concrete construction structural frame mass

\begin{tabular}{|c|c|c|c|c|c|c|}
\hline Floor & $\begin{array}{c}\text { Area } \\
\left(\mathrm{m}^{2}\right)\end{array}$ & Thickness of the Slab & $\begin{array}{l}\text { Unit Floor Mass } \\
\left(\mathrm{kg} / \mathrm{m}^{2}\right)\end{array}$ & $\begin{array}{l}\text { Mass of the slab } \\
(\mathrm{kg})\end{array}$ & $\begin{array}{c}\text { Mass of columns } \\
(\mathrm{kg})\end{array}$ & $\begin{array}{c}\text { Mass of beams } \\
(\mathrm{kg})\end{array}$ \\
\hline Ground & 72 & Lightweight bricks $(27 \mathrm{~cm})$ & 285 & 20520 & 8722 & 17076 \\
\hline First floor & 76 & Lightweight bricks $(27 \mathrm{~cm})$ & 285 & 21660 & 7810 & 15248 \\
\hline \multicolumn{6}{|c|}{ Mass of staircase } & 6000 \\
\hline \multicolumn{6}{|c|}{ Total mass of the reinforced concrete structural frame } & 97036 \\
\hline
\end{tabular}

Table 3 Lightweight steel construction structural frame mass

\begin{tabular}{|c|c|c|}
\hline \multicolumn{1}{|c|}{ Table 3 Lightweight steel construction structural frame mass } \\
\hline Mass of the Floors structure $(\mathrm{kg})$ & Mass of the walls structure $(\mathrm{kg})$ & Mass of the staircase $(\mathrm{kg})$ \\
\hline 4200 & 950 & 350 \\
\hline \multicolumn{2}{|c|}{ Total Mass of the lightweight structure frame } & \\
\hline
\end{tabular}

Table 4 Reinforced concrete construction total mass of the building

\begin{tabular}{|c|c|c|c|c|c|c|c|}
\hline Floor & $\begin{array}{c}\text { Area } \\
\left(\mathrm{m}^{2}\right)\end{array}$ & $\begin{array}{c}\text { Thickness of the } \\
\text { floor }\end{array}$ & $\begin{array}{c}\text { Unit floor mass } \\
\left(\mathrm{kg} / \mathrm{m}^{2}\right)\end{array}$ & $\begin{array}{c}\text { Mass of the floor } \\
(\mathrm{kg})\end{array}$ & $\begin{array}{c}\text { Mass of columns } \\
(\mathrm{kg})\end{array}$ & $\begin{array}{c}\text { Mass of beams } \\
(\mathrm{kg})\end{array}$ & $\begin{array}{c}\text { Total mass of the walls } \\
(\mathrm{kg})\end{array}$ \\
\hline Ground & 72 & $\begin{array}{c}\text { Lightweight } \\
\text { bricks }(27 \mathrm{~cm})\end{array}$ & 350 & 25200 & 8722 & 17076 \\
\hline First & 76 & $\begin{array}{c}\text { Lightweight } \\
\text { bricks }(27 \mathrm{~cm})\end{array}$ & 350 & 26600 & 7810 & 15248 \\
\hline \multicolumn{7}{|c|}{ Mass of the staircase } & 25075 \\
\hline \multicolumn{7}{|c|}{ Total mass of the reinforced concrete building } \\
\hline
\end{tabular}

Table 5 Lightweight steel construction total mass of the building

\begin{tabular}{|c|c|c|c|c|c|}
\hline Floor & $\begin{array}{c}\text { Area } \\
\left(\mathrm{m}^{2}\right)\end{array}$ & Thickness of the floor & $\begin{array}{c}\text { Unit floor mass } \\
\left(\mathrm{kg} / \mathrm{m}^{2}\right)\end{array}$ & $\begin{array}{c}\text { Mass of the floor } \\
(\mathrm{kg})\end{array}$ & 4320 \\
\hline Ground & 72 & $254 \mathrm{~mm}$ beam & 60 & 3800 \\
\hline First & 76 & Roof & 50 & 3597,50 \\
\hline \multicolumn{7}{|c|}{ Mass of staircase } & 4755 \\
\hline \multicolumn{2}{|c|}{ Total mass of the lightweight steel building } \\
\hline
\end{tabular}

\subsection{Weather Conditions}

In a construction site where lightweight steel construction method is adopted as the main design option, weather conditions do not create any impact on the construction activities. On the other hand, in a site where reinforced concrete construction method is being used weather conditions affect the construction activities. For example, in very hot countries like Saudi Arabia, pouring of concrete for in-situ reinforced concrete construction takes place at night in order to prevent the sudden evaporation of the water. Up until recently, in Turkey, most of the large scaled in-situ reinforced concrete construction sites were shutting down from the beginning of December until March in order to prevent the construction activity delays due to bad weather conditions. In this way contractors were hoping to get rid of the construction activity delays based additional costs.

\subsection{Installation of Plumping/Electrical Works, Doors and Windows}

Installation of relevant plumbing/electrical works such as heating, cooling, electrical, and water for the structure requires breaking of the wall of concrete elements (column, beam, slab etc.) when reinforced concrete construction is chosen as the design option. However, when lightweight steel construction is in charge, required holes and spaces for the necessary plumbing/electrical works can be done during the manufacturing process of the structural elements excluding the need for future breaking and repairing. This can also be counted as another cost lessening parameter for lightweight steel construction when compared with reinforced concrete construction due to lessening manpower and construction duration as well as lessening probable nuisances to the environment that occurs due to execution of breaking and repairing works.

Last but not least, it is rather noticeable through experience and observations that dimensions of window 
and door frames for reinforced concrete structure are not as accurate as lightweight steel construction. This is again due to elements of lightweight steel structures being manufactured in factory with the help of high technology involved machinery where manufacturing of in-situ reinforced concrete structures involves intense workmanship. Door and window frames' accuracy difference for the two alternative construction methods are depicted in Fig. 4.

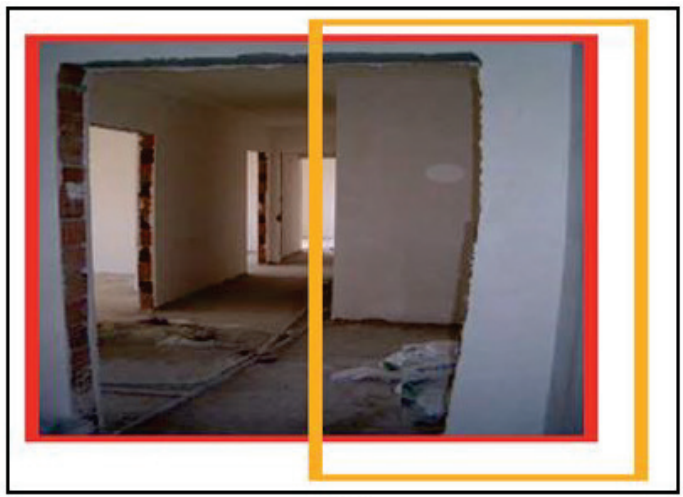

(a)

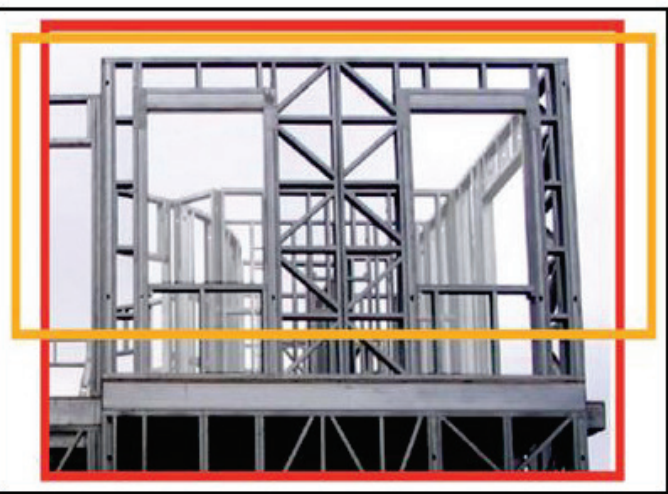

(b)

Figure 4 (a) Door frames' accuracy error for reinforced concrete structure, (b) Door frames' exact accuracy for lightweight steel structure

\subsection{Financial (Initial Cost)}

In this section, initial cost evaluations of the two alternative construction methods have concerned only the structural frame, walls and foundations of the buildings. Additionally, initial cost in this case is composed by summation of direct and indirect costs and was evaluated at the procurement phase via unit price estimation method depending on the historical data of the collaborated company.

Table 6 Total cost of a two-storey detached villa constructed by reinforced concrete

\begin{tabular}{|l|c|}
\hline \multicolumn{1}{|c|}{ Cost Items } & Total (Euro) \\
\hline Overhead expenses & 1312 \\
\hline Structural frame & 7424 \\
\hline Brickworks and internal plastering works & 2888 \\
\hline Roof construction and external plastering works & 3423 \\
\hline Total Cost & 15047 \\
\hline
\end{tabular}

Additionally, overhead expenses given in Tabs. 6 and 7 were composed through accumulation of project and company overheads. Furthermore, drivers of direct cost such as structural frame, brickworks and internal plastering works, and roof construction plus external plastering works that were provided in below given tables accommodate the equipment, labour, material, and subcontractor prices hence, each cost item is categorised as an element of direct cost. Since the cost data and work quantity were obtained from the collaborated contractor who is already practicing in the market and at the same time they were checked by the unit rates published by the Turkish authorities, the cost comparison is highly precise and reliable.

Table 7 Total cost of a two-storey detached villa constructed by lightweight steel

\begin{tabular}{|l|c|}
\hline \multicolumn{1}{|c|}{ Cost Items } & Total (Euro) \\
\hline Overhead expenses & 700 \\
\hline Structural frame & 7278 \\
\hline Walls and ceiling panels construction & 1158 \\
\hline Heat, sound and water isolation systems & 3233 \\
\hline Total Cost & 12369 \\
\hline
\end{tabular}

At the end of these calculations, it has been obtained that for this specific case, two-storey detached villa designed by reinforced concrete construction was $22 \%$ more expensive (in terms of gross floor area) compared to the villa designed by lightweight steel construction.

\subsection{Construction Duration}

Finishing a construction project in the shortest possible time provides various benefits such as cost savings on site management and on-site activities, reduction in cost of finance as shorter construction duration decreases the time for the duration of which interest has to be paid and providing earlier return on investment.

During the conducted comparison of two alternative construction methods in terms of duration, only; structural frame, walls and foundation of the building have been considered as the drivers of time.

In this specific case study, considering the organisational process assets of the collaborated company, the construction activity schedules for two building construction methods were prepared separately. In these scheduling, the accepted working hours were 8 hours per day and working days were 5 days per week (Mon-Fri).

Within this context, for a two-storey detached villa designed by reinforced concrete construction method, for the construction activities of structural frame, walls and foundation construction site was estimated to be open for 79 days.

On the other hand, in order to construct structural frame, walls and foundation of the two-storey detached villa designed by lightweight steel construction method, construction site was estimated to be open for 23 days. Therefore, it was obtained that the duration of reinforced concrete frame is $70.9 \%$ longer than that of lightweight steel frame.

\section{CONCLUSION}

In Europe, especially in Mediterranean countries currently, reinforced concrete construction is the dominant method of construction. Lightweight steel construction is rarely used. The main reason for not using lightweight steel construction is the lack of knowhow in engineers, architect and labours; therefore, the diffidence of contractor about lightweight steel construction. Lack of knowledge about 
lightweight steel construction breaks their confidence in considering the lightweight steel construction method.

It is worth to highlight that the two essential properties of using lightweight steel as structural element over reinforced concrete construction method are its lightweight and having shorter construction duration on the site. This construction method is highly advantageous in countries which are in highly risky earthquake regions.

With regard to the aforementioned conducted case study, from the architectural point of view, the dimensions of the structural elements used in reinforced concrete construction and lightweight steel construction have differences for the same internal usage area. Due to these differences, it is observed that total covered area of the villa designed by reinforced concrete construction is $2.6 \%$ larger. Moreover, total mass of the villa designed by reinforced concrete construction is 151.7 tonnes making it 9 times greater than the total mass of the villa designed by lightweight steel construction that is only 16.9 tonnes. For that reason, it is concluded that in case of any earthquake impact of the seismic activity will be 6 times greater for the villa designed by reinforced concrete.

Furthermore, it is possible to obtain more accurate finishing with the lightweight steel construction because of its significant advantage of being manufactured in factory medium. In terms of quality it can be said that lightweight steel construction is more stable than reinforced concrete construction. In addition, easiness in terms of installation of the plumbing/electrical works is greater when lightweight steel construction is in charge.

In addition, accumulation of direct and indirect costs for constructing the structural frame, walls and the foundation of the two-storey detached villa designed by reinforced concrete construction was roughly $€ 15047$. On the other hand, accumulation of the direct and indirect costs for constructing the same elements of the two-storey detached villa designed by lightweight steel construction was roughly $€ 12369$. In terms of construction duration, by adopting lightweight steel construction, it is possible to construct the structural frame, walls, and foundations of the two-storey detached villa $70.9 \%$ faster than reinforced concrete construction.

\section{REFERENCES}

[1] Bibby, G. (2006). Structures update. Building Magazine, 3, 64-69.

[2] Idrus, A. \& Newman, J. (2003). IFESS: a computer tool to aid structural engineers at the conceptual design stage. Construction Innovation, 3, 127-143. https://doi.org/10.1108/14714170310814891

[3] Haroglu, H., Glass, J., \& Thorpe, T. (2009). A study of professional perspectives on structural frame selection. Construction Management and Economics, 27(12), 12091217. https://doi.org/10.1080/01446190903233129

[4] WSA. World Steel Association. 2010 http://www.worldsteel.org (Accessed 26.01.2010)

[5] Mashhadifarahani, S. (2015). Light Weight Steel Frames vs. Common Building Structures - Structural performance Evaluation. American Scientific Research Journal for Engineering, Technology, and Sciences (ASRJETS), 12(1), 222-229.

[6] BCSA. The British Constructional Steelwork Association. 2006. https://www.steelconstruction.org (Accessed 17.01.2010)
[7] Çelik, T. (2010). Gap analysis for the potential use of steel construction in Cyprus. Dissertation, Loughborough University.

[8] Yu, W. (1999). Cold-Formed Steel Structures. CRC Press LLC. Boca Raton.

[9] ELSCA. European Lightweight Steel Framed Construction. 2005. https://www.constructalia.eu/english/publications/ technical_guides/european_lightweight_steel_frame_constr uction\#.V3eQveBRVdg (Accessed 28.07.2010)

[10] Yu, W. (1991). Cold-Formed Steel Design. John Wiley \& Sons, New York.

[11] Rhodes, J. (1991). Design of Cold-Formed Steel Structure. Elsevier Publishing, New York.

[12] Hancock, G. (1994). Cold-Formed Steel Structures. Australian Institute of Steel Construction, North Sydney.

[13] SISC. Swedish Institute of Steel Construction, Sweden, 1982.

[14] BSI. British Standards Institution, UK, 1987.

[15] SA. Standards Australia, Australia, 1996.

[16] AISI. American Iron and Steel Institute, Washington DC, USA, 1996.

[17] CSA. Canadian Standards Association. Ottawa, Canada, 1994.

[18] PRCNS. People's Republic of China National Standard. Beijing, China, 1989.

[19] FME. Finnish Ministry of Environment. Finland, 1988.

[20] CTICM. Centre Technique Industriel de la Construction Metallique. France, 1978

[21] DIN. DIN 18807. Deutsche Norm. Germany, 1987.

[22] ISI. Indian Standards Institution. India, 1975.

[23] AIJ. Architectural Institute of Japan. Japan, 1985.

[24] GSF. Groep Stelling Fabrikanten. Netherlands, 1977.

[25] SNZ. Standards New Zealand. New Zealand, 1996.

[26] SAISC. South African Institute of Steel Construction. South Africa, 1995

[27] ECCS. European Convention for Constructional Steelwork. London, UK, 1987.

[28] BCSA. Steel Buildings Silver Book. $1^{\text {st }}$ ed., London, Box of Tricks, London, 2004

[29] Sirikci, I. (2006). Çelik bir Sistemin Elastik ve Plastik Analiz Sonuçlarının Betonarme Sistemle Maliyet Karşılaştırılması. Dissertation (in Turkish), Kahramanmaras Sutcu Imam University.

[30] CSSBI. Environmental Fact Sheet: Lightweight Steel Framing - Looking forward to the benefits. 2014. http://cssbi.ca/assets/resources/Enviro_Fact_Sheet/CSSBIEFS3-14.pdf (Accessed 16.06.2016).

[31] Zhang, X., Su, X., \& Huang, Z. (2007). Comparison of LCA on Steel-and concrete-construction office buildings: A case study. College of Mechanical Engineering, Tongji University.

[32] CSSBI. An introduction to residential steel framing. 1994. http://www.cssbi.ca/Eng/_pdf/CSSBI-54-94.pdf (Accessed 28.07.2010)

[33] Tam, V. W. Y. (2011). Rate of Reusable and Recyclable Waste in Construction. The Open Waste Management Journal, 4, 28-32. https://doi.org/10.2174/1876400201104010028

[34] Teo, M. M. M. \& Loosemore, M. (2001). A theory of waste behaviour in the construction industry. Construction Management \& Economics, 19(7), 741-751. https://doi.org/10.1080/01446190110067037

[35] Chen, Z., Li, H., \& Wong, C. T. C. (2002). An application of bar-code system for reducing construction wastes. Automation in Construction, 11(5), 521-533. https://doi.org/10.1016/S0926-5805(01)00063-2

[36] Yu, W. W. \& LaBoube, R. A. (2010). Cold-Formed Steel Design. $4^{\text {th }}$ ed., Wiley. https://doi.org/10.1002/9780470949825 
[37] Çelik, T. (2014). Developing a Building Construction Associated Social Cost Estimation System for Turkish Construction Industry, Dissertation, University of Salford.

\section{Contact information:}

Tolga Çelik, PhD

Department of Civil Engineering,

Eastern Mediterranean University,

Famagusta, T. R. North Cyprus, Via Mersin 10, Turkey

tolga.celik@emu.edu.tr

\section{Saeed KAMALI, MSc}

Civil Engineering Department

Middle East Technical University

Ankara, Turkey

saeedkamali2002@gmail.com 